\title{
Iron and steel technology: options for India
}

\author{
S RAMACHANDRAN \\ Foundation to Aid Industrial Recovery, Materials Research Centre, PB No 2522, Richmond \\ Town, Bangalore 560025 , India
}

\begin{abstract}
Steel has been known in India since hoary antiquity and it is referred to in the Vedas as Ayas (Heath 1839). It has been deduced from archeological evidence that ancient Indians knew the art of making steel. In this article this old history as well as the recent history of iron and steelmaking is briefly reviewed, the challenges posed for the iron and steel industry are explored and finally prospects for iron and steelmaking in India are evaluated.
\end{abstract}

Keywords. Ironmaking; steelmaking; history; Indian context.

\section{Introduction}

In engineering usage, iron usually refers to iron-based alloys in which carbon concentration is at a saturation level. Steel is an alloy where the carbon level is below saturation levels and adjusted as required for a particular application. Historically, steel was the first to be produced and used. This is attributable to the use of insufficient carbon used in reduction of ores, and to carbon loss during forging. When man learnt to produce flames and heat up materials to a temperature of $1300^{\circ} \mathrm{C}$, carbon-saturated iron was readily produced. Carbon-saturated iron is a brittle material and as soon as techniques for refining molten iron to steel were developed, strong and pliable steel regained its dominance. Historically man first learned the manufacture and use of steel then for a short interlude made and used iron and today uses mainly steel.

The carbon content in steel is adjusted as required for a particular application. Steel also contains other alloying elements. Today, in the production of iron and steel significant amounts of alloy elements such as manganese, chromium, nickel, molybdenum, niobium, etc, are used and this often accounts for the major industrial use of these elements.

\section{Iron and steel in India}

\subsection{Genesis}

An excellent and brief presentation of the genesis and growth of iron and steel in India has been published by Sidhu (1983). "The metal is referred to in Vedic literature as Ayas. The antiquity of the Indian process is no less astonishing than its ingenuity. The tools with which the Egyptians carved their obelisks and temples and covered them with hieroglyphics were made of Indian steel. There is no evidence to show that any of the nations of antiquity besides the Hindus were acquainted with the art of making steel. The references which occur in Greek and Latin writings on this subject served only to reveal their ignorance of it; they were familiar with the use of steel, but they appear to have been altogether ignorant of the mode by which it was prepared from iron." 
Sir Robert Hadfield writing in the Journal of Iron and Steel Institute remarks, "Without doubt, therefore, the process of making iron and steel has been used in India for thousands of years . . . . It may, therefore, easily have been the case that the ancient Egyptians were familiar with Indian iron and steel and either imported the material or obtained the services of Indian workers in metals to produce the necessary materials for the tools employed on the great stone monuments. The chain of evidence at least appears to be complete that the knowledge of how to produce and work iron and steel had been acquired in times of antiquity. Heath, therefore, probably rightly claims that the Hindus had been familiar with the manufacture of steel from time immemorial and he held the same opinion as the author (Hadfield) that the stone works of Egypt could only have been carried out by tools of iron, probably cemented or hardened steel" (Hadfield 1912).

The famous iron pillars located near Kutub Minar at Delhi and at Indore are lasting evidence of the metallurgical knowhow of the ancient Indians. In fact, many scholars opine that the famous Damascus steel is nothing but Indian steel produced in some of the inaccessible villages of Madras and Hyderabad (Nirmal) (Rao 1974, 1982a). The traders of Damascus found it profitable enough to travel regularly to these inaccessible villages to acquire the raw material for the manufacture of weapons. Even in more recent times when the modern steel industry had yet to appear in Europe, the cutlers of Great Britain imported the metal from India and rated it of a better quality than the Swedish iron which they frequently imported. In fact, Sir Hadfield who examined a piece of the iron pillar at the Kutub Minar remarked that the piece was free from slag and other impurities. It was of better quality than anything metallurgists were able to produce currently and the composition was similar to that of ancient iron from Ceylon.

The process of producing steel from the ore was described in Ain-i-Akbari a chronicle of the life, events and history of the Great Mughal. It states that artisans at Nirmal (presently a small town in the Telengana area of Andhra Pradesh) reduced powdered magnetite and haematite in small, but flattish, slightly convex crucibles, using wood or green leaves as reducing and carburising agents. The product obtained was a small cake of steel, few inches in diameter, evidencing at the top vitrified slag in melted iron and dense steel at the bottom. This steel was widely sought in Persia and Central Asia for making the so-called Damascus blades. The cakes of high carbon woot $z$ or Indian steel were heated and beaten into blades. Some of the metallurgists of the 19th century notably Mushet opined that the raw steel for these blades was made by direct reduction of very pure iron ore in small crucibles (Dilley \& Macbride 1967; Rickard 1929).

\subsection{Iron and steel industry $1850-1950$}

J M Heath, a civil servant of the East India Company posted at Porto Novo, started an iron smelter in 1830. The ore for the smelter was obtained from the South Arcot district, whereas the Boypur (Malabar) works obtained their ore supplies from Calicut and Feroke. The East India Iron Company, which was formed in London in the year 1853, located its smelters and works at Tiruvanamalai. These works used 5 tonnes of wood to produce a tonne of charcoal and two tonnes of charcoal for making one tonne of iron. The units at Tiruvanamalai and at Pulampalli used only magnetite ore. As the production was undertaken in very trying conditions with irregular ore and charcoal supplies, the works incurred losses and were closed in 1858 and 1867. The company was liquidated in 1874. 
In West Bengal, the smelting of iron ore was in relatively better shape. In 1852, about 72 furnaces were reported to be in operation. Around 1839, Jessop \& Co. conducted experiments in the smelting of the iron ore of Burdwan with coke. In 1874, Burn \& Co. deputed Mr Hughes to examine the iron ores of Burdwan and coal from Raniganj, who despatched the samples to England. They were tested by Dr C W Siemens in his furnace. He reported that for making a tonne of puddling bar iron, 2.75 tonnes of ores and 2.25 tonnes of coal were needed and would cost about 22 to 23 shillings per tonne of iron which included general expenses and labour costs.

The Bengal Iron Works which came into existence in 1874 started two blast furnaces at Kulti. The company acquired coal mines also for feeding the furnaces. In 1869, the works were transferred to another private party, Martin \& Company. Subsequently, a new company known as SCOB (Steel Corporation of Bengal) was set up in the beginning of the present century. The company established four blast furnaces and attained a capacity of 500 tonnes of iron per day. The present day Indian Iron and Steel Company was found in 1918 with modern steel-making facilities at Burnpur by British interests in Calcutta. In the early thirties, the IISCO acquired SCOB and merged it into one unit in 1953.

J N Tata (head of the Tata House) a successful merchant and a textile mill owner, obtained a licence for setting up a modern iron and steel works at the end of the 19th century. The services of German geologists and American steel makers were procured for locating raw materials and designing the plant. The search for a proper location fructified two years after J N Tata's death. The Sakchi site chosen for locating the mill was ideal in many respects. The location had a water source adjacent to the plant and the ore was only a few miles away, but the coal source was relatively distant. From the beginning, the plant was oriented towards steel production for the growing Indian market, rather than the production of pig iron for export.

The Tatas first tried to interest British investors in the venture, who, however, demanded a degree of con:rol of the unit's management which the Tatas were unwilling to concede. Left with no choice, but convinced of the soundness of the scheme and encouraged by the then prevailing nationalist and Swadeshi sentiments, Tatas went to the market for a public subscription in 1907 for Rs. $2 \cdot 3$ crores. The issue was an instant success due to the existence of a favourable image of the Tata House as good managers of industry and trade, strong Swadeshi sentiments and the prosperous parsee community.

The establishment of the plant received help and co-operation of the Government of India by way of a grant of Zamindari and leases for mines. Technical advice and production skills were liberally imported. In fact, the first Indian General Manager of the Works was appointed only in the mid-thirties. For the first four decades, the plant was under continuous expansion from $1,00,000$ tonnes in 1912 to $8,00,000$ tonnes in 1939. The expansion was financed through retained profits, depreciation funds and borrowing in the London money market. To soothe the restive and irate shareholders, R D Tata (at the meeting held on June 24, 1925) appealed to their nationalist sentiments: "Make no mistake about this point. We hold this money in trust for you. But you hold this money in trust for the Indian nation".

After independence, Government allowed the Tatas to expand capacity to 2 million tonnes of ingot steel. Tatas wanted to expand further and submitted proposals for establishing a new plant at Adityapur, a site adjacent to the present Sakchi plant, which did not materialise. The Mysore Iron \& Steel Works was founded by the State of 
Mysore in 1918 to use the charcoal produced at the wood distillation plant. The wood distillation plant became obsolete with the advent of the distillation of synthetic wood. However, the charcoal furnace continued to produce iron. Steel production facilities were added in the mid-thirties. In the early fifties, an electric furnace for ore smelting was established. Presently, the complex produces alloy steels, ferro-alloys and a small quantity of mild steel. The name of the works also changed to Visveswaraya Iron and Steel Limited.

The consumption of steel in the country increased considerably during the second World War. The two domestic units, TISCO and IIsco desired to expand their capacity. However, the Government appointed a committee to study domestic steel requirements. The committee recommended that two new units should be established with 0.5 million tonne capacity each to be scaled up to 1 million tonnes. Again, the new Government after Independence commissioned three foreign firms to assess the feasibility of establishing new units and they confirmed the recommendations of the earlier committee.

\subsection{Post-Independence era}

The Indian and non-Indian bodies, asked to look into the steel needs of the country, were in favour of expanding the-steel industry, through the establishment of two new units. The industrial policy resolution (1948) clearly stated that all future growth of the steel industry should be reserved for the public sector. It further indicated that the existing units in the private sector may also be nationalised, if warranted. During the first plan period, TISco expanded its capacity to two million tonnes along with extensive modernisation and rehabilitation of the old plant. The expansion of the Mysore unit, though approved initially, was ultimately scrapped.

The second Plan which went into operation in 1956 set the steel targets at almost three times that of the actual output in 1956. In 1953, the German firm, Krupps-Damag agreed to establish the country's first public sector unit to be located at Rourkela. The project report for the one million tonne capacity Rourkela Plant was submitted in 1955 and it was fully commissioned by 1962 . In early 1955, the Soviet Union agreed to set up the country's second steel plant at Bhilai in Madhya Pradesh. The project report for the Bhilai Steel plant (one million tonne capacity) was submitted in December, 1955, and its capacity was fully commissioned in January, 1961.

In 1954, the Birlas, a leading industrial house of India, submitted a proposal to set up a steel mill. The Birlas earlier concluded an agreement with a consortium of British firms manufacturing equipment for steel plants. The industrial policy resolution had reserved the steel industry for the public sector. Additionally, the private sector was programmed to supply only 10 per cent of the investment and the balance was to come from Government of India and British sources. British loans were to be guaranteed by the Government. Government justifiably considered these conditions a breach of the industrial policy, unwarranted in the circumstances, as Government, under this scheme, would either be supplying or assuring ninety per cent of the investment. The proposal was, therefore, rejected. A few months Iater, the Government concluded an agreement with the same consortium on better terms of credit, for setting up a steel plant at Durgapur. The project report for the Durgapur plant was submitted in 1956 and its one million tonne capacity was fully commissioned by 1962.

The setting up of India's fourth public sector steel plant at Bokaro is a story by itself. 
The history of the plant is an interesting example of foreign aid. One can regard the building of the Bokaro steel plant like the Aswan Dam construction in Egypt, as a unique event in the history of us-Soviet Aid rivalry. It also exemplified the problems of seeking, receiving and utilisation of foreign aid.

Bokaro was one of the sites considered by the Colombo Plan Mission in 1955. The Mission had five locations in view, two areas near Sindri, one near Durgapur in West Bengal and two areas near the present Bokaro Steel City in Bihar. The Mission favoured the Durgapur site rejecting two Bokaro sites as they required substantial investment in infrastructure creation. The Government of India, while accepting Durgapur as a plant site, also decided to develop Bokaro as a possible future location. In fact, the Ministry of Steel and Mines asked for financial allocation for site development.

The Bokaro steel project was a magnificent obsession of the nation as a first step towards self-reliance. A note floated in the Planning Commission (Bokaro Steel Project-Problems of Implementation) fully reflects the dreams and aspirations of the nation and the hopes of the great statesman, Prime Minister Nehru. The note orchestrates the national aspirations for establishing a self-reliant heavy industrial structure that confers the necessary degree of freedom from external dependence both in methods and materials. It was this transcending vision of the project, beyond the prosaic task of setting up a million tonne steel ingot capacity, that imparted it with grandeur and turned it into a "magnificent obsession." The Planning Commission's note envisaged maximum possible use of indigenous consultancy, design, equipment and construction skills. It also assumed that aid would be forthcoming from the USA. A request for us aid was put forth by India. The us Congress and the us Steel Industry opposed the project purely on ideological considerations. In addition, the Americans desired the operational control of the plant by them for at least some years as a precondition which was not acceptable to the Government of India. The request was, therefore, withdrawn by the Government of India even before the stage of negotiation.

As huge capacities for machine and equipment building had been created at Heavy Engineering Corporation and MAMC, the country was anxious to utilise these capacities by setting up a Steel Plant. India accepted the Soviet offer of aid for establishing the Bokaro Steel Plant. Construction work started in 1966 and the first blast furnace was to have been commissioned in 1969 , though this furnace was actually commissioned in 1972. This indicated a delay of 27 months on account of various factors, like non-receipt of working drawings, equipment, structurals and materials from different sources. The Soviet Union was supposed to supply 37,9 and $10 \%$, respectively, of the total equipment, structurals and refractories needed for plant construction and erection. The balance of equipment and other supplies were to be made available by indigenous sources including public sector undertakings. The plants first stage capacity of 1.70 million was reached only 1979, a gestation lag of 13 years.

The plant capacities and capacity utilisation of iron \& steel are shown in tables 1-3. This story will not be complete without a discussion of the development of mini-steel plants in India. In the mid-sixties, the capacity of the re-rolling industry touched a level of more than 3 million tonnes (on a two shift basis). These re-rolling mills used either billets (when available) or discarded materials from the railways to make products like bars and rods used mainly in construction activity. The integrated steel plants during the mid-sixties were unable to keep pace with the level of demand for billets and the premium on mild steel products because use in construction activity touched very high 
Table 1. Plant capacities in $1979-80$

\begin{tabular}{|c|c|c|c|}
\hline Name of the plant & $\begin{array}{l}\text { Ironmaking } \\
\text { (hot metal) }\end{array}$ & Steelmaking & Products \\
\hline Bokaro & $\begin{array}{l}3 \mathrm{BF} \\
2000 \mathrm{M}^{3}\end{array}$ & $4 \mathrm{LD} 100 \mathrm{~T}$ & $\begin{array}{l}\text { Blooms, slabs, } \\
\text { strip, coils, } \\
\text { plates, sheets }\end{array}$ \\
\hline Durgapur & $\begin{array}{l}3 \text { BF } 1171 \mathrm{M}^{3} \\
1 \text { BF } 1550 \mathrm{M}^{3}\end{array}$ & 8 ОНF-220 T & $\begin{array}{l}\text { Blooms, slabs, } \\
\text { sleepers, bars, } \\
\text { merchant products, } \\
\text { skelp, wheels and } \\
\text { axles, sections }\end{array}$ \\
\hline IISCO & $\begin{array}{l}3 \text { BF } 500 M^{3} \\
2 \text { BF } 1140 \cdot M^{3}\end{array}$ & $\begin{array}{l}3 \text { Bessemer } \\
6 \text { OHF }\end{array}$ & $\begin{array}{l}\text { Bars and rods, } \\
\text { heavy rails, } \\
\text { light rails, black } \\
\text { and galvanised sheets }\end{array}$ \\
\hline TISCO & $\begin{array}{l}1 \mathrm{BF}-558 \mathrm{M}^{3} \\
2 \mathrm{BF}-633 \mathrm{M}^{3} \\
2 \mathrm{BF}-1939 \mathrm{M}^{3} \\
1 \mathrm{BF}-1337 \mathrm{M}^{3}\end{array}$ & $\begin{array}{l}15 \text { OHF }-190 \mathrm{~T} \\
2 \text { OHF- } 250 \mathrm{~T} \\
3 \text { LD } 25 \mathrm{~T} \\
2 \mathrm{EAF}\end{array}$ & $\begin{array}{l}\text { Rails, bars and } \\
\text { structural plates } \\
\text { sheets, strips, } \\
\text { wheels, axles, tyres }\end{array}$ \\
\hline Rourkela & $\begin{array}{l}3 \text { BF } 1135 \mathrm{M}^{3} \\
1 \mathrm{BF} 1660 \mathrm{M}^{3}\end{array}$ & $\begin{array}{l}4 \text { OHF } 800 \mathrm{~T} \\
3 \mathrm{LD} 40 / 50 \mathrm{~T} \\
2 \mathrm{LD} 60 \mathrm{~T}\end{array}$ & $\begin{array}{l}\text { Slabs, plates } \\
\text { cold hot coils, } \\
\text { sheets, sect. coils, } \\
\text { strips, pipes }\end{array}$ \\
\hline Bhilai & $\begin{array}{l}3 \text { BF } 1033 \mathrm{M}^{3} \\
2 \text { BF } 1719 \mathrm{M}^{3}\end{array}$ & $\begin{array}{l}5 \text { OHF } 250 \mathrm{~T} \\
5 \text { OHF } 500 \mathrm{~T}\end{array}$ & $\begin{array}{l}\text { Blooms, billets, } \\
\text { rails, structurals } \\
\text { and squares, wire rods }\end{array}$ \\
\hline VISL & $\begin{array}{l}2 \text { ESF (Pig) } 100 \mathrm{~T} / \text { day } \\
2 \mathrm{ESF} \text { (Iron) } 200 \mathrm{~T} / \text { day }\end{array}$ & $\begin{array}{l}5 \text { OHF } 25 \mathrm{~T} \\
2 \text { LD } 15 \mathrm{~T} \\
3 \text { Electric arc }\end{array}$ & $\begin{array}{l}\text { Blooms, bars, } \\
\text { sheets, forgings }\end{array}$ \\
\hline
\end{tabular}

levels. The electric steel producing units which were in existence in the pre-1965 period were mainly producing steel castings, alloys or special steels. These units faced serious recessionary conditions because of the lack of demand for their products and many were closed. It was realised then that the mild steel products for construction purposes commanded a premium that provided enough margin to electric arc furnaces for producing billets.

To improve the economic viability of electric arc furnace steel (mini-steel) units, the Government at the end of 1966 allowed them to produce mild steel ingots to meet the demand for construction steel. Later, the Government delicensed the electric furnace industry like other industries which had an investment of less than Rs. 10 million. Encouraged by the delicensing policy of the Government, a few units came up to produce exclusively mild steel ingots. However, in 1970, the Government again brought the electric furnace industry under the purview of the licensing regulation to ensure a stable supply of inputs like scrap and electric power. The delicensing policy and incentives provided by the Government (by imposing a lower excise duty on the ingots made by these electric furnaces) resulted in a fast growth, though haphazard, of the socalled mini-steel plants.

In the western world, mini-steel plants are units with a good deal of forward integration i.e. with capabilities for production of ingots as well as finished products 
Table 2. Hot metal capacity utilisation (Production as percentage of rated capacity)

\begin{tabular}{|c|c|c|c|c|c|c|}
\hline & Bhilai & Durgapur & Rourkela & IISCO & TISCO & Bokaro \\
\hline Rated output & $100-0$ & $100-0$ & $100-0$ & $100-0$ & $100-0$ & $100-0$ \\
\hline $1959-60$ & 91.9 & $16 \cdot 8$ & $62 \cdot 5$ & $82 \cdot 3$ & $83 \cdot 7$ & \\
\hline $1960-61$ & $82 \cdot 7$ & $59 \cdot 3$ & $58 \cdot 2$ & $89 \cdot 3$ & $83 \cdot 5$ & \\
\hline $1961-62$ & 85.9 & $100 \cdot 3$ & $60-0$ & $91 \cdot 3$ & $86 \cdot 6$ & \\
\hline $1962-63$ & $100 \cdot 1$ & $104 \cdot 5$ & $72 \cdot 9$ & $99 \cdot 4$ & $92 \cdot 8$ & \\
\hline $1963-64$ & $109 \cdot 81$ & $122 \cdot 8$ & $78 \cdot 2$ & $95 \cdot 2$ & $95 \cdot 2$ & \\
\hline $1964-65$ & $99 \cdot 5$ & 123.9 & $93 \cdot 0$ & $89 \cdot 5$ & $99 \cdot 2$ & \\
\hline $1965-66$ & $91 \cdot 7$ & $120 \cdot 7$ & $99 \cdot 4$ & $93 \cdot 7$ & $101 \cdot 0$ & \\
\hline $1966-67$ & $109 \cdot 2$ & $65 \cdot 4$ & $68 \cdot 2$ & $90-5$ & $101 \cdot 4$ & \\
\hline $1967-68$ & $88 \cdot 1$ & $59 \cdot 9$ & $58 \cdot 5$ & $83 \cdot 8$ & 90.9 & \\
\hline $1968-69$ & 81.9 & $71 \cdot 7$ & $77 \cdot 7$ & $88 \cdot 2$ & $90 \cdot 4$ & \\
\hline $1969-70$ & $82 \cdot 3$ & $72 \cdot 9$ & $74 \cdot 2$ & $84 \cdot 6$ & $85 \cdot 6$ & \\
\hline $1970-72$ & $91 \cdot 2$ & 607 & $71 \cdot 6$ & $71 \cdot 5$ & 87.6 & \\
\hline $1971-73$ & 77.8 & 600 & 606 & 700 & 86.0 & \\
\hline $1972-74$ & $78 \cdot 4$ & 61.0 & $77 \cdot 6$ & $53 \cdot 8$ & $88 \cdot 5$ & \\
\hline $1973-75$ & $75 \cdot 6$ & $57 \cdot 6$ & $75 \cdot 1$ & $58 \cdot 6$ & 87.8 & \\
\hline $1974-77$ & $81 \cdot 2$ & $64 \cdot 2$ & $86 \cdot 3$ & $70 \cdot 5$ & 86.9 & \\
\hline $1975-78$ & $94 \cdot 1$ & $76 \cdot 3$ & $91 \cdot 3$ & $72 \cdot 2$ & $92 \cdot 4$ & \\
\hline $1976-79$ & 908 & $70 \cdot 9$ & $82 \cdot 8$ & 69.8 & $92 \cdot 7$ & \\
\hline $1979-80$ & $84 \cdot 8$ & 61.9 & 82.8 & $66 \cdot 0$ & 88.0 & $80-0$ \\
\hline $1980-81$ & $75 \cdot 4$ & 57.8 & $78 \cdot 2$ & $53 \cdot 1$ & $79 \cdot 8$ & 61.9 \\
\hline \multirow[t]{2}{*}{$1981-82$} & 74.5 & $48 \cdot 2$ & 76.7 & 60.6 & 86.7 & 61.4 \\
\hline & $87 \cdot 2$ & $72 \cdot 2$ & $73 \cdot 4$ & $80-8$ & $89 \cdot 2$ & 68.8 \\
\hline
\end{tabular}

Table 3. Capacity utilisation of saleable steel (as percentage of rated capacity)

\begin{tabular}{|c|c|c|c|c|c|c|}
\hline & Bhilai & Durgapur & Rourkela & TISCO & ISCO & Bokaro \\
\hline Rated capacity & $100 \cdot 0$ & 1000 & $100 \cdot 0$ & $100 \cdot 0$ & $100 \cdot 0$ & 1000 \\
\hline $1973-74$ & 85.6 & $30-4$ & 600 & 78.8 & 44.8 & \\
\hline $1974-75$ & $86 \cdot 2$ & $42 \cdot 0$ & $66 \cdot 3$ & 95.9 & $51 \cdot 8$ & \\
\hline $1975-76$ & $94 \cdot 1$ & $60 \cdot 7$ & $85 \cdot 0$ & 97.5 & $62 \cdot 5$ & \\
\hline $1976-77$ & $102 \cdot 7$ & $72 \cdot 8$ & 95.9 & $101 \cdot 7$ & $67 \cdot 7$ & \\
\hline $1977-78$ & 98.7 & $69 \cdot 8$ & $96 \cdot 2$ & $105 \cdot 1$ & $63 \cdot 2$ & \\
\hline $1978 \sim 79$ & $94 \cdot 0$ & $63 \cdot 0$ & $85 \cdot 0$ & 99.5 & $60-0$ & \\
\hline $1979-80$ & 86.8 & $48 \cdot 8$ & $85 \cdot 2$ & $95 \cdot 0$ & 53.8 & $43 \cdot 1$ \\
\hline $1980-81$ & $92 \cdot 5$ & $48 \cdot 3$ & $80 \cdot 4$ & $100 \cdot 9$ & 65.4 & $42 \cdot 8$ \\
\hline $1981-82$ & $92 \cdot 6$ & $63 \cdot 1$ & 89.0 & 105.4 & $61 \cdot 0$ & $74 \cdot 7$ \\
\hline $1982-83$ & 93.5 & $65 \cdot 7$ & $81 \cdot 0$ & 106.4 & $62 \cdot 5$ & $77 \cdot 4$ \\
\hline
\end{tabular}

whereas in India such units are few. The licensed capacity and regional distribution of electric furnace steel plants are presented in tables 4 and 5 . The production and capacity utilisation is shown in table 6 . 
Table 4. Category-wise mini-steel plant licensed capacity in 1967-77

\begin{tabular}{lccc}
\hline Licenced to produce & $\begin{array}{c}\text { No. of } \\
\text { units }\end{array}$ & $\begin{array}{c}\text { No. of } \\
\text { furnaces }\end{array}$ & $\begin{array}{c}\text { Liquid metal } \\
\text { capacity (in tonnes) }\end{array}$ \\
\hline Alloy steel & 8 & 21 & 472,000 \\
Steel castings & 44 & 83 & 704,000 \\
Ingots and castings & 17 & 52 & 667,000 \\
Plain carbon & 117 & 159 & 2618,000 \\
Special & 1 & 2 & 54,000 \\
Total & 187 & 317 & $4,515,000$ \\
\hline
\end{tabular}

Table 5. Regional distribution of electric arc furnaces in India

\begin{tabular}{|c|c|c|c|c|c|c|c|}
\hline \multirow[b]{2}{*}{ Region } & \multirow[b]{2}{*}{$\begin{array}{l}\text { No. of } \\
\text { units }\end{array}$} & \multicolumn{4}{|c|}{$\begin{array}{l}\text { No. of furnaces with capacity } \\
\text { (tonnes) }\end{array}$} & \multicolumn{2}{|c|}{$\begin{array}{l}\text { Liquid metal } \\
\text { capacity (tonnes) }\end{array}$} \\
\hline & & Below 5 & $5-10$ & $10-15$ & $15 \&$ above & $\begin{array}{l}\text { Total no. } \\
\text { of furnaces }\end{array}$ & $\begin{array}{c}\text { Total } \\
\text { capacity }\end{array}$ \\
\hline North & 60 & 12 & 17 & 26 & 43 & 98 & $1,377,000$ \\
\hline East & 44 & 9 & 14 & 19 & 45 & 87 & $1,252,000$ \\
\hline South & 29 & 14 & 4 & 17 & 16 & 51 & 734,000 \\
\hline West & 54 & 17 & 15 & 20 & 29 & 81 & $1,152,000$ \\
\hline Total & 187 & 52 & 50 & 82 & 133 & 317 & $4,515,000$ \\
\hline
\end{tabular}

Table 6. Production and capacity utilisation of mini-steel plants (in million tonnes)

\begin{tabular}{ccccccc}
\hline Year & $\begin{array}{c}\text { Mild steel } \\
\text { capacity }\end{array}$ & $\begin{array}{c}\text { Alloys } \\
\text { castings } \\
\text { capacity }\end{array}$ & $\begin{array}{c}\text { Mild steel } \\
\text { output }\end{array}$ & $\begin{array}{c}\text { col. 4 } \\
\text { as of } \\
\text { col. 2 }\end{array}$ & $\begin{array}{c}\text { Output } \\
\text { alloy \& } \\
\text { castings }\end{array}$ & $\begin{array}{c}\text { col. 6 } \\
\text { as \% of } \\
\text { col. 2 }\end{array}$ \\
\hline 1 & 2 & 3 & 4 & 5 & 6 & 7 \\
\hline $1970-71$ & 1.71 & 0.66 & 0.43 & 24.1 & 0.28 & 42.4 \\
$1971-72$ & 1.80 & 0.66 & 0.53 & 29.4 & 0.30 & 45.5 \\
$1972-73$ & 2.33 & 0.66 & 0.67 & 28.8 & 0.32 & 48.5 \\
$1973-74$ & 2.50 & 0.66 & 0.67 & 26.8 & 0.36 & 51.5 \\
$1974-75$ & 2.68 & 0.65 & 0.53 & 19.8 & 0.26 & 42.4 \\
$1975-76$ & 2.68 & 0.66 & 0.72 & 26.9 & 0.32 & 48.5 \\
$1976-77$ & 2.70 & 0.66 & 0.91 & 33.7 & 0.33 & 50.0 \\
$1977-78$ & 2.70 & 0.70 & 0.99 & 36.7 & 0.34 & 48.6 \\
$1978-79$ & 2.70 & 0.70 & 1.49 & $55 \cdot 2$ & 0.35 & 50.0 \\
$1979-80$ & 2.72 & 0.70 & 0.45 & 53.3 & 0.34 & 48.6 \\
\hline
\end{tabular}

\section{Current technology}

The production of steel can be classified into two broad categories. The first category includes process sequences that start with iron ore as the major source for iron units and the second which utilizes metallic iron (recycled scrap) as the major raw material. The former class of steel plants are termed integrated steel plants. 
The steel produced is then cast and formed into shapes such as strips, rods, beams, etc, which are supplied to the steel user. About $80 \%$ of the energy and $60 \%$ of the costs are incurred in the making of molten steel. The discussion of the status of our technology will therefore be restricted to the production of molten steel.

\subsection{Iron}

In iron ore-based technology, the blast furnace-based units account for over $97 \%$ of the iron ore converted to metallic iron. The blast furnace uses coke as fuel and produces molten iron. It is at least as old as the industrial era. One can even argue that the early Indian furnace was a precursor of the blast furnace. Those furnaces as also the early blast furnace used charcoal as fuel and the start of the modern industrial era coincides with the time when it was modified to accept anthracite coal and later coke.

Today the blast furnace is a highly technologically efficient process (figure 1 is a schematic representation of the modern blast furnace). It has a very broad range of tolerance factors for raw material quality. It initially used charcoal as the reductant but as the size of the furnace increased the scarcity of charcoal necessitated a switch to anthracite coal and then to artificially prepared low volatile carbonaceous coke. Iron ores with a high $\mathrm{Fe}$ content are directly used as feed material in lumpy form whereas lower grade ores are beneficiated and used after sintering or pelletising. The use of prepared materials has enhanced the productivity of the furnaces and the size of the furnaces have gradually increased and a production of around 2.5 million tonnes per year is possible in some of the giant furnaces of today.

The progress of the blast furnace technology in India is not so impressive. In the early sixties the coke rates and slag rates of Indian blast furnaces were comparable to the best blast furnaces in the world. Today our furnaces are plagued with poor productivity, high coke and slag rates. Table 7 presents a comparison of the coke rate of blast

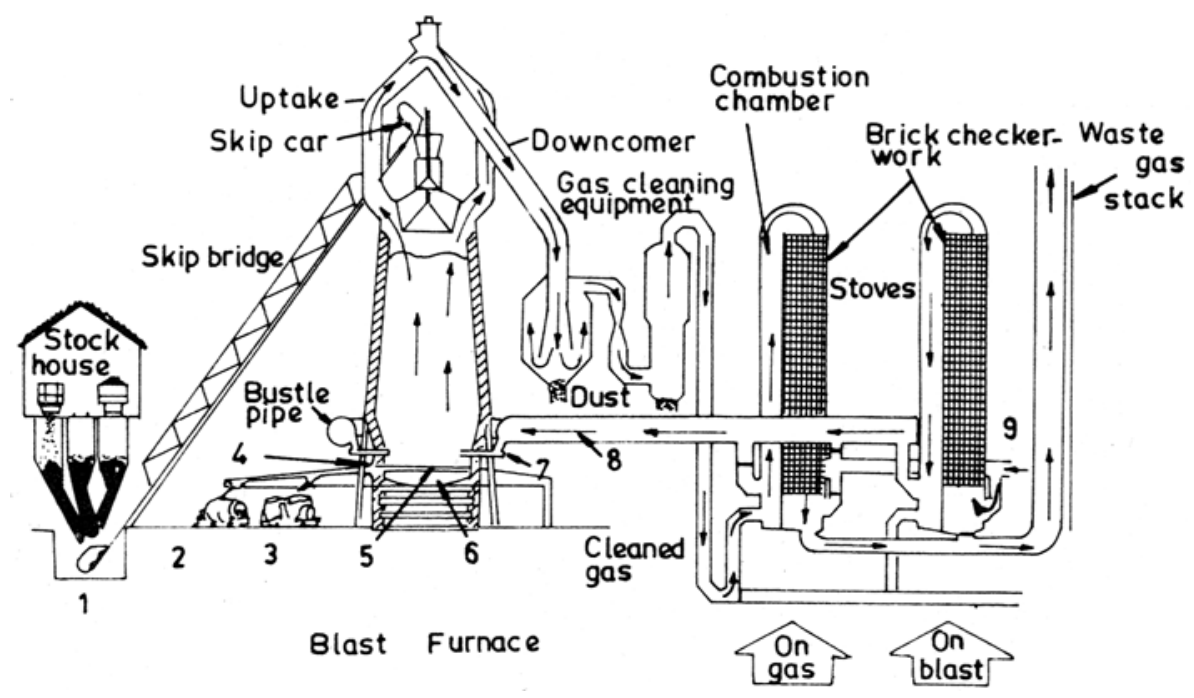

Figure 1. Schematic cross-section of a blast furnace plant: 1) chutes-ore, coke and limestone, 2) hot metal car, 3) slag ladle, 4) iron and slag notches, 5) molten slag, 6) molten iron, 7) tuyeres, 8) hot blast, 9) cold blast 
Table 7. Coke consumption per tonne of hot metal (in $\mathrm{kg}$ per tonne)

\begin{tabular}{lrrrrrr}
\hline & 1950 & 1955 & 1960 & 1965 & 1970 & 1973 \\
\hline Belgium & $780(100)$ & $876(110)$ & $844(106)$ & $646(81)$ & $584(73)$ & $555(69)$ \\
France & $994(100)$ & $1022(103)$ & $972(98)$ & $784(79)$ & $526(63)$ & $560(56)$ \\
Germany (FRG) & $947(100)$ & $946(100)$ & $834(88)$ & $672(71)$ & $559(59)$ & $495(52)$ \\
Japan & $910(100)$ & $723(80)$ & $619(68)$ & $507(56)$ & $473(53)$ & $435(47)$ \\
UK & $1027(100)$ & $982(96)$ & $826(80)$ & $680(66)$ & $625(61)$ & $575(56)$ \\
USA & $933(100)$ & $851(91)$ & $770(83)$ & $650(70)$ & $658(71)$ & $602(65)$ \\
USSR & $944(100)$ & $\mathbf{8 8 0 ( 9 3 )}$ & $724(77)$ & $586(62)$ & $575(61)$ & N.A. \\
\hline
\end{tabular}

Figures in brackets are oil consumption in $\mathbf{k g} /$ tonne

Table 8. Coke consumption in $\mathrm{kg}$ per tonne of hot metal of Indian steel plants

\begin{tabular}{lcccccc}
\hline Year & Bhilai & Rourkela & Durgapur & $\begin{array}{c}\text { IISco } \\
\text { (wet Coke) }\end{array}$ & $\begin{array}{c}\text { risco } \\
\text { (wokaro }\end{array}$ \\
\hline $1966-67$ & 792 & 936 & 925 & 941 & 823 & - \\
$1967-68$ & 839 & 963 & 913 & 946 & 868 & - \\
$1968-69$ & 845 & 962 & 905 & 1015 & 877 & - \\
$1970-71$ & 810 & 901 & 930 & 981 & 934 & - \\
$1971-72$ & 810 & 928 & 949 & 986 & 921 & - \\
$1972-73$ & 808 & N.A. & N.A. & 1087 & N.A. & - \\
$1973-74$ & 800 & 952 & 845 & 1146 & N.A. & - \\
$1974-75$ & 779 & 925 & 1005 & 1065 & N.A. & 752 \\
$1975-76$ & 794 & 934 & 1002 & 1029 & 893 & 698 \\
$1976-77$ & 792 & 919 & 872 & 1063 & 839 & 700 \\
$1977-78$ & 828 & 909 & 912 & 1089 & 828 & 698 \\
$1978-79$ & 843 & 929 & 939 & 1097 & 795 & 693 \\
$1979-80$ & 850 & 907 & 1003 & 1142 & 807 & 756 \\
$1980-81$ & 840 & 875 & 1017 & - & 800 & 777 \\
$1981-82$ & 842 & 835 & 957 & 1151 & 804 & 759 \\
$1982-83$ & 823 & 890 & 901 & 1072 & 818 & 752 \\
\hline
\end{tabular}

furnaces in various countries. Details regarding coke rates for Indian blast furnaces are presented in table 8 . Table 9 shows a comparison of the coke and slag rates and the productivity of blast furnaces in India. Figures for a Japanese blast furnace are included for comparison.

The better performance of the Japanese can be attributed in part to the use of choice raw materials and is reflected in their low slag rates. This upgrading of blast furnace performance has also been the pattern in most other countries (table 7) and is attributable to better raw materials and improved practices. The lack of improvement in India is obvious and is partly due to the fact that our raw materials base is fixed and that there has been some deterioration in raw material quality. On the Indian scene the Bokaro performance reflects the effect of improved technology which is still much below the performances reported elsewhere. When one compares raw material quality, the poor quality of Indian Coal, especially its ash content, makes it obvious that it is one of the prime reasons for our low performance. Compared to coke ash of $6-10 \%$ in other countries our coke contains over $20 \%$ ash. It can be seen that upgrading of our raw materials is desirable and the development of special technologies would be useful. 
Table 9. Blast furnace performance indices in India

\begin{tabular}{|c|c|c|c|c|c|c|}
\hline \multirow[b]{2}{*}{ Plant } & \multicolumn{2}{|c|}{$\begin{array}{r}\text { Productivity } \\
\mathrm{THM} / \mathbf{M}^{3} / \text { day }\end{array}$} & \multicolumn{2}{|c|}{$\begin{array}{r}\text { Coke rate } \\
\mathrm{kg} / \mathrm{THM}\end{array}$} & \multicolumn{2}{|c|}{$\begin{array}{r}\text { Slag rate } \\
\mathrm{kg} / \text { THM }\end{array}$} \\
\hline & $\max$ & $\min$ & $\max$ & $\min$ & $\max$ & $\min$ \\
\hline 1 & 2 & 3 & 4 & 5 & 6 & 7 \\
\hline \multicolumn{7}{|l|}{ Japanese data } \\
\hline $\begin{array}{l}\text { Fakuyama BF of } \\
\text { NKK (1981) }\end{array}$ & $2 \cdot 4$ & 1.9 & 450 & 340 & - & 247 \\
\hline \multicolumn{7}{|l|}{ Bhilai steel plant } \\
\hline BF no. 1 & $1 \cdot 17$ & 0.74 & 900 & 699 & 650 & 550 \\
\hline BF no. 2 & $1 \cdot 02$ & 0.64 & 870 & 800 & 640 & 560 \\
\hline BF no. 3 & $1 \cdot 11$ & 0.90 & 920 & 830 & 620 & 550 \\
\hline BF no. 4 & 0.84 & 0.60 & 960 & 820 & 600 & 520 \\
\hline BF no. 5 & 0.95 & 0.83 & 870 & 830 & 580 & 480 \\
\hline BF no. 6 & 0.98 & 0.74 & 880 & 760 & 570 & 570 \\
\hline \multicolumn{7}{|l|}{ Bokaro steel plant } \\
\hline BF no. 1 & 0.96 & 0.50 & 870 & 644 & 580 & 500 \\
\hline BF no. 2 & 0.95 & $0 \cdot 70$ & 740 & 630 & 560 & 490 \\
\hline BF no. 3 & $1 \cdot 16$ & 0.89 & 720 & 630 & 540 & 470 \\
\hline \multicolumn{7}{|l|}{ Durgapur steel plant } \\
\hline BF no. 1 & 0.78 & $0 \cdot 61$ & 980 & 920 & 630 & $\$ 40$ \\
\hline BF no. 3 & 0.76 & 0.40 & 1130 & 910 & 650 & 560 \\
\hline BF no. 4 & 0.49 & $0 \cdot 75$ & 910 & 830 & 580 & 510 \\
\hline \multirow[t]{4}{*}{ IISCO } & $1 \cdot 16$ & 0.59 & 1310 & 940 & 600 & 340 \\
\hline & 1.07 & 0.46 & 1380 & 1020 & 580 & 340 \\
\hline & 0.72 & 0.49 & 1140 & 940 & 690 & 560 \\
\hline & 0.76 & $0 \cdot 49$ & 1120 & 930 & 680 & 570 \\
\hline \multicolumn{7}{|l|}{ Kalinga iron works } \\
\hline BF no. 1 & $2 \cdot 10$ & 1.40 & 1600 & 1320 & 800 & 770 \\
\hline BF no. 2 & 1.7 & 0.60 & 1700 & 1040 & 700 & 550 \\
\hline BF no. 3 & 17 & 0.50 & 1660 & 1180 & 775 & 560 \\
\hline \multicolumn{7}{|l|}{ Rourkela steel plant } \\
\hline BF no. 1 & 0.88 & 0.48 & 1040 & 840 & 750 & 600 \\
\hline BF no. 2 & 0.87 & 0.66 & 1060 & 900 & 720 & 610 \\
\hline BF no. 3 & 0.96 & $0-68$ & 990 & 810 & 710 & 610 \\
\hline BF no. 4 & 0.71 & $0 \cdot 45$ & 1000 & 860 & 810 & 590 \\
\hline \multirow[t]{5}{*}{ TISCO } & 0.86 & 0.60 & 920 & 740 & 700 & 600 \\
\hline & 1.00 & 0.65 & 900 & 710 & 700 & 600 \\
\hline & 1.03 & $0 \cdot 21$ & 1120 & 780 & 690 & 530 \\
\hline & 1.02 & $0 \cdot 36$ & 910 & 720 & 660 & 530 \\
\hline & 1.01 & $0 \cdot 36$ & 1000 & 680 & 760 & 590 \\
\hline$B F$ no. $F$ & 1.06 & $0 \cdot 70$ & 870 & 750 & 660 & 530 \\
\hline
\end{tabular}

Source: Blast furnace and sintering plant operating committee, Fifth Annual Report (1978-1979), Vol. 2, SAIL, RDCIS, Ranchi.

These problems are unique to our country and as such no one has worked out practical solutions, and the investment on a search for such solutions (viz research and development) has been meagre in India (table 10). 
Table 10. Annual expenditure of salt, $R$ \& $D$ Centre for iron \& steel, Ranchi

\begin{tabular}{|c|c|c|c|}
\hline \multirow[b]{2}{*}{ Year } & \multicolumn{3}{|c|}{ Expenditure in lakhs (Rs.) } \\
\hline & Capital & Operational & Total \\
\hline $1972-73$ & 0.0 & 200 & 2.00 \\
\hline $1973-74$ & 0.10 & 15.00 & 1500 \\
\hline $1974-75$ & 0.50 & $21 \cdot 60$ & $22 \cdot 10$ \\
\hline $1975-76$ & 23.45 & 37.99 & 61.44 \\
\hline $1976-77$ & 19.66 & 47.97 & 67.63 \\
\hline $1977-78$ & $16 \cdot 47$ & 103.90 & $120 \cdot 37$ \\
\hline $1978-79$ & 35.01 & $120 \cdot 13$ & $155 \cdot 14$ \\
\hline $1979-80$ & 246.89 & 188.37 & 435.26 \\
\hline $1980-81$ & $408 \cdot 29$ & $260 \cdot 17$ & $669 \cdot 00$ \\
\hline $1981-82$ & $766 \cdot 63$ & $366 \cdot 81$ & 113.44 \\
\hline $\begin{array}{l}\text { 1982-83 } \\
\text { (Provisional) }\end{array}$ & $679 \cdot 46$ & 575.93 & $1255 \cdot 39$ \\
\hline
\end{tabular}

Source: SAIL, RDCIS, Ranchi, Annual Report 1983.

\subsection{Steel}

The first industrial process for steelmaking was the Bessemer process in which molten iron is converted to steel by blowing air through ceramic tuyeres located at the bottom of the furnace (figure 2). The process was quickly superceded by the basic open hearth process in which the molten iron is refined in a shallow hearth under a coal or oil fired flame (figure 3). Soon the open hearth process accounted for over $85 \%$ of steel production and by the middle of the century (the 1950's), the basic open hearths and electric furnaces accounted for the bulk of the steel production.

In 1952, a new process was put into operation in Austria (Gaines 1974). This was the culmination of years of experimentation and development involving a number of people. The objective was to use pure oxygen to refine molten iron. The idea was first mooted by Bessemer but had to await the discovery of practical and economic methods

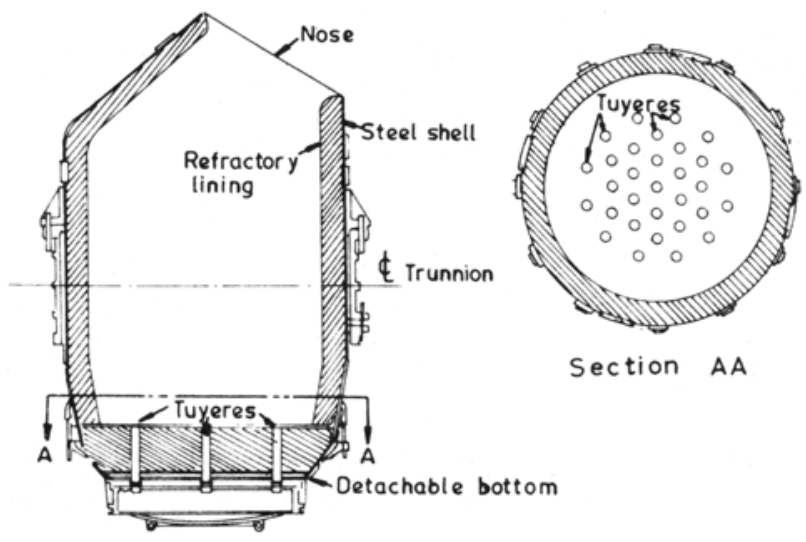

Figure 2. Schematic cross-section of a Bessemer converter 


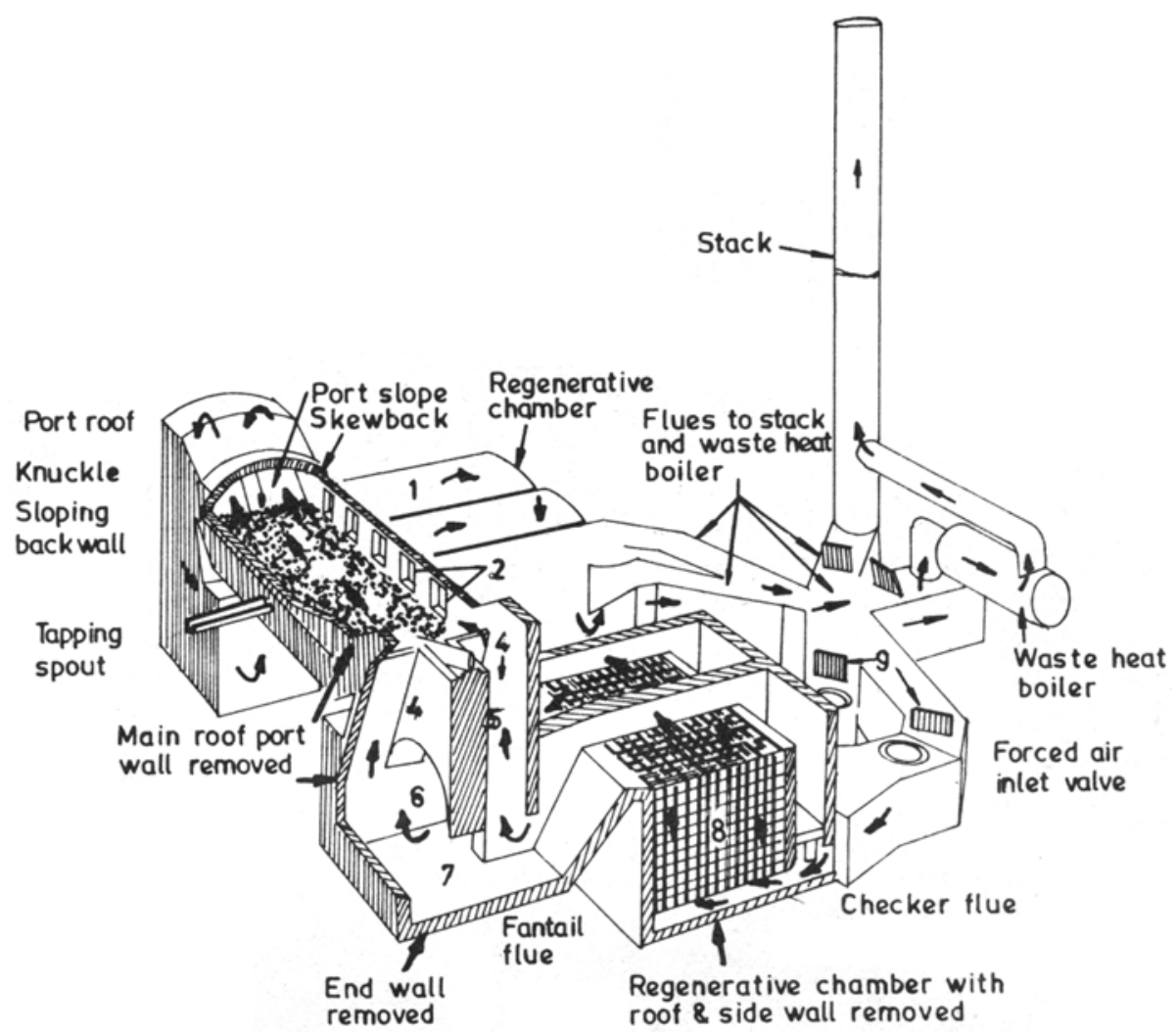

Figure 3. Schematic diagram of an open hearth furnace plant: 1) front wall, 2) charging doors, 3) bath, 4) uptake, 5) burner, 6) burner arch, 7) slag pocket, 8) checkers, 9) dampers

of making tonnage oxygen by liquid air fractionation, the development of water-cooled lances and the development of good quality basic refractories. A schematic view of the basic oxygen furnace is given in figure 4 . In this furnace molten iron and the requisite quantity of scrap are placed. Oxygen is blown into this charge through nozzles placed in a water-cooled retractable top lance. The oxygen combines with carbon and metalloids such as silicon and manganese to form oxides. The carbon monoxide leaves as a gas while the other oxides form part of the slag. A fraction of the iron is also oxidized. The heat generated by the reactions is sufficient to melt about $30 \%$ of the charge. The refining is very rapid, a batch of steel is made within 30 minutes in contrast to steelmaking in the open hearths which takes several hours. This process has rapidly displaced the open hearth process for steelmaking and since the early sixties no new open hearth facilities have been installed.

In the late 50's when we expanded our capacity, the Government decided to install this new process to make a portion of the steel at Rourkela. We were one of the early pioneers in installing this process. The history of the technological performance of steelmaking in India also displays a static level of performance while in all other countries, improvements have been continuous. 


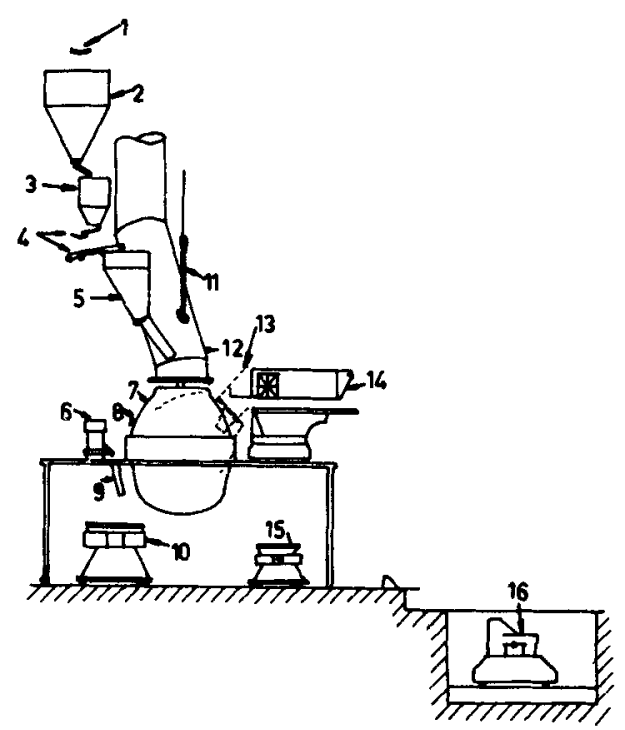

Figure 4. Schematic diagram of a typical BOF plant: 1) conveyor from raw material storage, 2) storage bins, 3) weighing bins, 4) conveyors, 5) batching hopper, 6) ladle additive transfer car, 7) furnace, 8) taphole, 9) ohute, 10) teeming ladle on transfer car, 11) oxygen lance, 12) hood, 13) positions of tilted furnace and scrap box, when charging scrap (dotted lines) 14) scrap charging car, 15) slag pot on transfer car, 16) hot-metal transfer ladle on transfer car in pit

\section{The challenges}

\subsection{Ironmaking}

Our record thus far has been a mixed one. We have embarked on a largely successful programme of iron and steel expansion but technologically have not been outstanding. Our country possesses all the raw materials necessary for iron and steelmaking. The technology practised currently is not the best for our materials. It is to be noted that the bulk of the costs of steelmaking consists of raw material and manpower costs (Boylan 1975) and hence it is necessary that we continue to be self-sufficient in steel production. Only about a decade ago have we initiated extensive efforts towards improving our steel technology as evidenced by the investments in research and development by the iron and steel industry (table 10). In this section, the prospects for existing and new technologies will be assessed. To continue to use the blast furnace for Indian materials requires that the materials be upgraded or the process parameters be drastically modified, otherwise we accept the low performance.

The raw materials can be beneficiated only when they are pulverized to a suitable liberation size. Such pulverized matter cannot be fed directly to the blast furnace which is a shaft furnace. Beneficiated materials have to be agglomerated. In the case of iron ore, pelletizing or sintering is feasible. Pelletizing is a more expensive process. Fluxes can and should be upgraded and used in the sinter or pellet. Coal can be de-ashed and the coking process modified to accept the beneficiated coal. Alternatively, part of the charge can be fed into the process directly. Direct injection of coal has become commercial practice in USA (Stephenson 1983) and has been experimented on in USSR. 
The coal can be non-coking coal and can be beneficiated to a low ash coal. Upto $150 \mathrm{~kg}$ per tonne of coal can be injected into the process. By increasing the heat input in the tuyere, other raw materials can be injected into the furnace. Iron ore fines can be prereduced and injected into the tuyeres using a plasma heated blast. A number of novel techniques can be suggested. On paper, each technique can be evaluated and the performance and cost targets mapped out for each of these suggestions.

Unfortunately there is no history or understanding of the value of such speculations in technology in India. This speculation is to be followed up by actual trials to understand the limits for performance. A recent paper (Kajikawa et al 1983) illustrates the systematic and scientific approach used by Japan. To quote the paper "Some low fuel rate trial operations have been carried out to clarify the problems and the furnace phenomena of extremely low fuel rate operations. NKK carried out the trial operation at its $3223 \mathrm{~m}^{3}$ blast furnace. . . A record monthly mean fuel rate of $396 \mathrm{~kg} / \mathrm{t}$ was achieved in November 1981 ". They conclude that the findings obtained from the present operation suggest the direction of future research and development. This primary focus of gaining a sound understanding of processes enables the Japanese steelmaker to achieve a mastery of technology which he can use gainfully when necessary.

The modern blast furnace complexes are usually built as larger units in order to achieve economies of scale. It also requires good quality coking coal. With an annual consumption of steel of around 9 million tonnes, the setting up of giant 2 million tonne plants is difficult. Also, our coking coal reserves are in the Bengal-Bihar area while the ore is distributed more widely. It has been economically less remunerative to set up steel plants in ore regions located far away from the coking coal reserves. Added to this is the cost of beneficiation of raw materials to match world quality. Alternative processes for ironmaking that are economically viable in small sizes and more tolerant of raw material quality would be desirable. Fortunately, there are now several developments nearing the stage of commercial testing that offer exciting prospects.

The first of these alternate routes, is an old idea that has been now well researched, engineered and technically proven. This is the rotary kiln process of direct reduction of iron ore (figure 5). In this process, coal is burnt in a rotary kiln in a controlled manner such that it heats and reduces iron ore fed as lumps or pellets. The process works for a

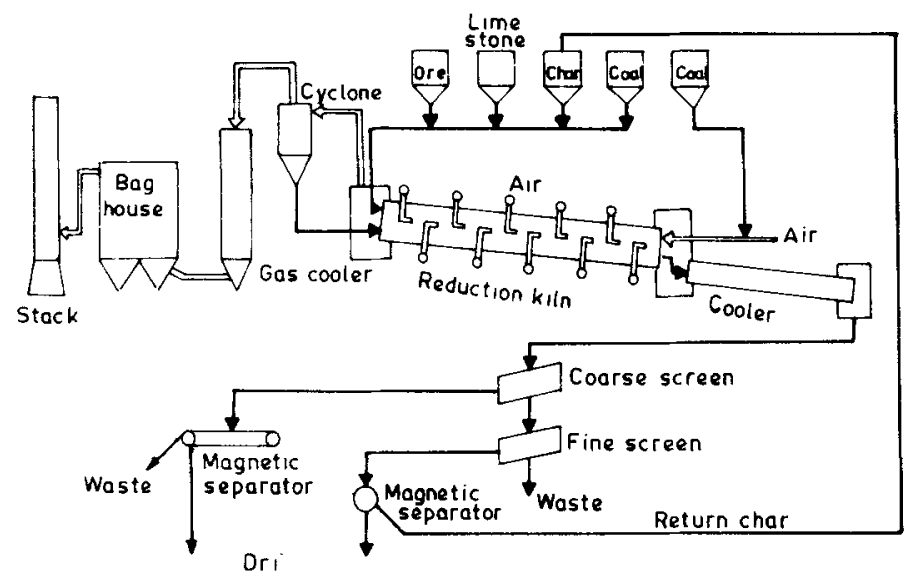

Figure 5. Flowsheet of a rotary kiln plant 
restrictive set of raw material combinations and has been successfully utilized under special conditions (Stephenson 1980). Several variants of this process have been developed in India; three variants of the process are now being tried out, a fourth variant was tested by NML and has now been abandoned (Chatterjee et al 1982). A 30,000 tonne per year plant using SL/RN technology has been in operation since 1981 at Kothagudem in Andhra. A 160,000 tonne per year plant using ACCAR technology has been installed in Orissa. Recently tisco has announced the setting up of a 90,000 tonne per year plant in collaboration with the Orissa Government. The advantages claimed for all these technologies are: (i) small economic unit size $(100,000$ tonne per year) (ii) ability to use very poor grades of non-coking coal.

The disadvantages are: (i) the high quality of ore required, (ii) restriction on coal quality, specially fusion characteristics (iii) low energy efficiency.

Proposals have been made to improve the overall energy efficiency by installing waste heat boilers for the offgas and by using fluidized bed boilers for using the waste char generated by the process. It has also been suggt sted that an electric smelting furnace can be adapted to smelt the reduced ore. This should help utilize pre-reduced ore fines and allow the use of lower grade ores. In the Indian context, the ability to use low grade non-coking coal is a definite advantage but the overall economics of the process and restrictions on ore quality are detractions (Lownie et al 1982; Hogan \& Koelble 1981).

More recent developments on direct smelting offer better prospects. There are a large number of processes in various stages of development. Three have reached a precommercial stage of testing. All of them claim that they can produce molten iron using mainly non-coking coal in plants with capacities in the range of $100,000-400,000$ tonnes per year and that cost of iron could be cheaper by 10-25\% than blast furnace ( 1.5 million tonne per year blast furnace capacity) iron and can produce steel at $25-50 \%$ cheaper cost than by direct reduction-electric arc furnace route.

The claims are impressive and have to be checked out for Indian materials. They can be confirmed when a relevant size semi-commercial or commercial plant is built. The three processes are known as the Inred, the Plasmasmelt and the Kohl reduction (KR) process.

The Inred and the Plasmasmelt processes use fine ores and powdered non-coking coal. The Plasmasmelt also uses a very small quantity $(50 \mathrm{~kg})$ of coke and requires power. The KR process uses ore lumps, sinter or pellets and non-coking coal of $2 \mathrm{~mm}-40 \mathrm{~mm}$ sizes. As the Inred and the Plasmasmelt use fine ore and coal, the beneficiated materials can be directly used and raw material of optimal quality can be used. Agglomeration will be required for the KR process. The status of each of these processes is reviewed as these processes offer exciting prospects to our iron and steel industry.

\subsection{The Inred process}

In the Inred process (Boliden AB, Sweden) (Elvander, et al, 1979; Elvander 1982; Irving 1981), fine-grained iron ore concentrates are reduced to molten iron in two stages in a single reactor. In the first stage, flash smelting of the concentrate by coal and oxygen is accomplished. The ore is pre-reduced to $\mathrm{FeO}$ and the charge is superheated. In this step, about $90 \%$ of the process energy is supplied. Coal supplied at the same time is partly burnt, the remainder forming coke. The pre-reduced and heated material is collected with the coke from the first stage in the lower part of the reactor. Here, the remaining 
part of the energy is supplied in the form of electrical energy. A schematic diagram of the Inred iron plant is given in figure 6.

Although the pilot unit included induction heating, Boliden Inred AB are now using submerged arc heating with self-baking electrodes. The flash-smelting chamber is constructed with water-cooled walls. The central gas off-take at the top of the reactor is also similarly designed. A waste heat boiler cools the hot exhaust gases producing reactor (smelting furnace), the oxygen plant $\left(95 \% \mathrm{O}_{2}\right.$ purity) and the fans, motors etc., required for the process. Inred needs electrical energy from a grid only for the start-up. Once the process is in operation, it is sufficiently balanced such that the electrical energy required is generated using the waste-heat boiler steam.

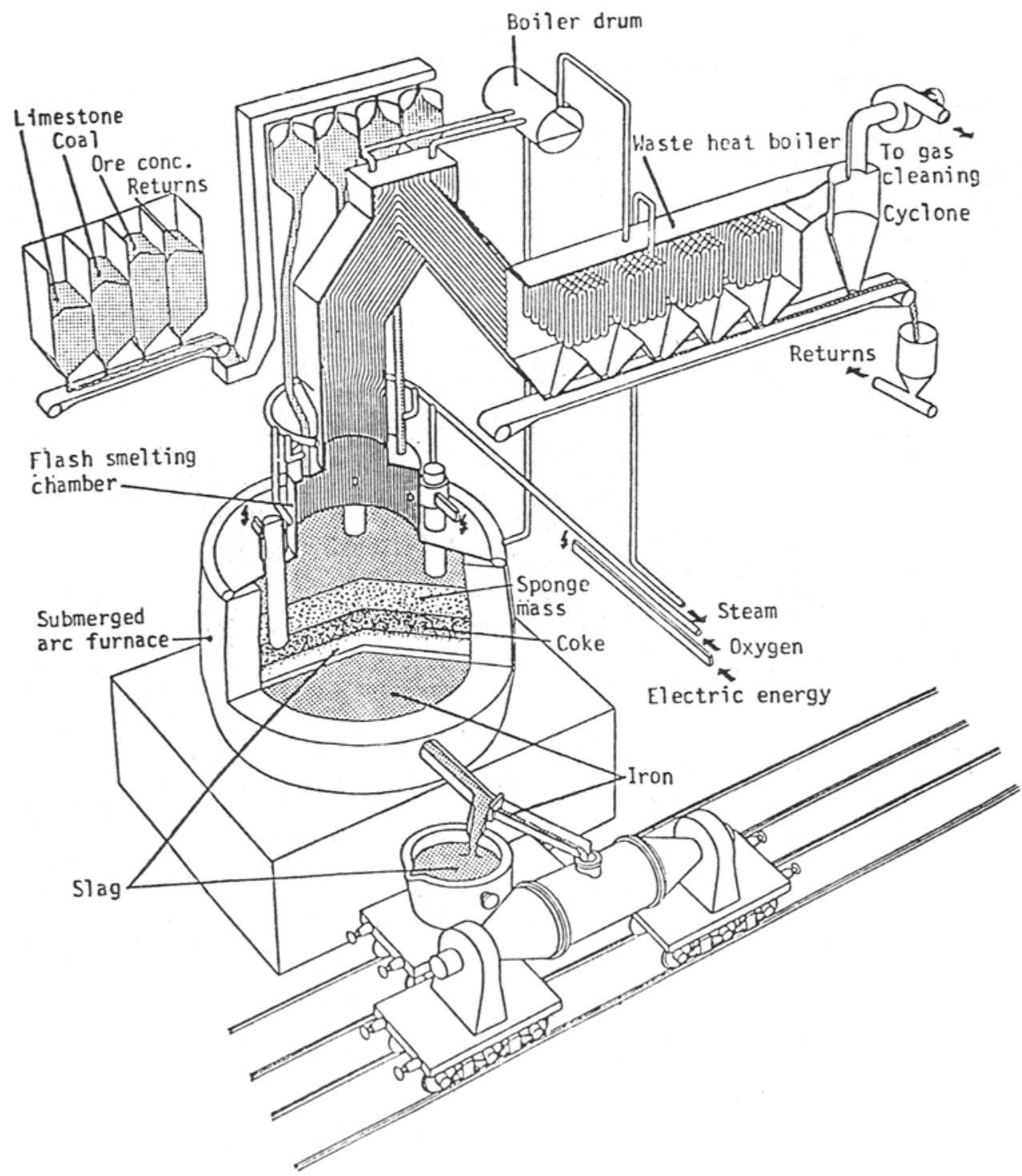

Figure 6. Schematic diagram of an Inred plant 
The temperature in the flash smelting (upper) section of the process reactor is estimated to be about $1900^{\circ} \mathrm{C}$, while in the lower section it is about $1450^{\circ} \mathrm{C}$. The iron (hot metal) produced has a carbon content of about $3.5 \%$. About $80 \%$ of the sulphur in the raw material feed is carried away by the waste gas and dust bleed, the balance being distributed between slag and iron with a partition ratio of 25 when the slag has an iron content below $1 \%$. Recovery of phosphorous by the melt is about $50 \%$ of the phosphorous present in the coal and about $85 \%$ of that present in the ore. Silicon is partly reduced into the iron, and the silicon content is higher at high temperatures and with well reduced slag.

\subsection{The KR process}

The KR-process (Korf Engineering-W. Germany, Voest Alpine-Austria) (Anon 1982; Mastey 1982; KR-short for "kohlereduktion", which means coal reduction in German) is also a cokeless approach to ironmaking. Figure 7 gives a schematic diagram of the KR-process plant. Expressed in simplified terms, the KR plant represents a blast furnace divided into a melter gasifier and a reduction shaft furnace.

In the melter gasifier hot $\left(800^{\circ} \mathrm{C}\right)$ direct reduced iron is converted to hot metal by the excess heat generated during the partial oxidation of coal. The coal charged into this melter gasifier (grain size up to $30 \mathrm{~mm}$ ) is gasified in a fluidized bed using oxygen. The gas produced consists of approximately $95 \% \mathrm{CO}+\mathrm{H}_{2}$. The melter gasifier in the $\mathrm{KR}$ process assumes the function of the blast furnace hearth where coke is gasified with the hot blast and the ore reduced in the shaft is melted to, hot metal. Since there is no supporting stand for the burden in the $\mathrm{kR}$ melter gasifier, the reduction zone must be separated from the melter gasifier by a mechanical metering device.

The reduction shaft with the hot discharge of DRI is located above the melter gasifier. After preliminary cleaning and temperature adjustment the hot reduction gas generated in the melter gasifier is directly conveyed to the reduction shaft to reduce the lump ore and/or pellets.

The top gas from the reduction shaft furnace and the balance of gas not required for direct reduction together represent a high valuable byproduct from hot metal production. The net calorific value of the gas is $\approx 8,400 \mathrm{~kJ} / \mathrm{Nm}^{3}\left(2,000 \mathrm{kcal} / \mathrm{Nm}^{3}\right.$; $225 \mathrm{BTU} / \mathrm{SCF}$ ). The export gas can be used for different applications:

-as fuel gas within the steel plant, in a pelletizing plant or to be sold to others,

-for generation of the oxygen required for gasification within the plant,

-for generation of electrical energy,

-for separate production of direct reduced iron.

The KR process is a combination of a new melter gasifier and proven shaft furnace technology for the reduction of iron ore. All calculations and tests have shown that even in smaller units this new process can well complete with large blast furnaces and gas reduction plants with regard to investment and operating costs.

\subsection{The Plasmasmelt process}

SKF has developed the Plasmasmelt process (Hebbert 1981) for the production of liquid hot metal by means of plasma technology. The use of the plasma generator for heating provides higher thermal efficiency than is obtained with conventional combustion. The objective in using two stages instead of one is to achieve a balance 


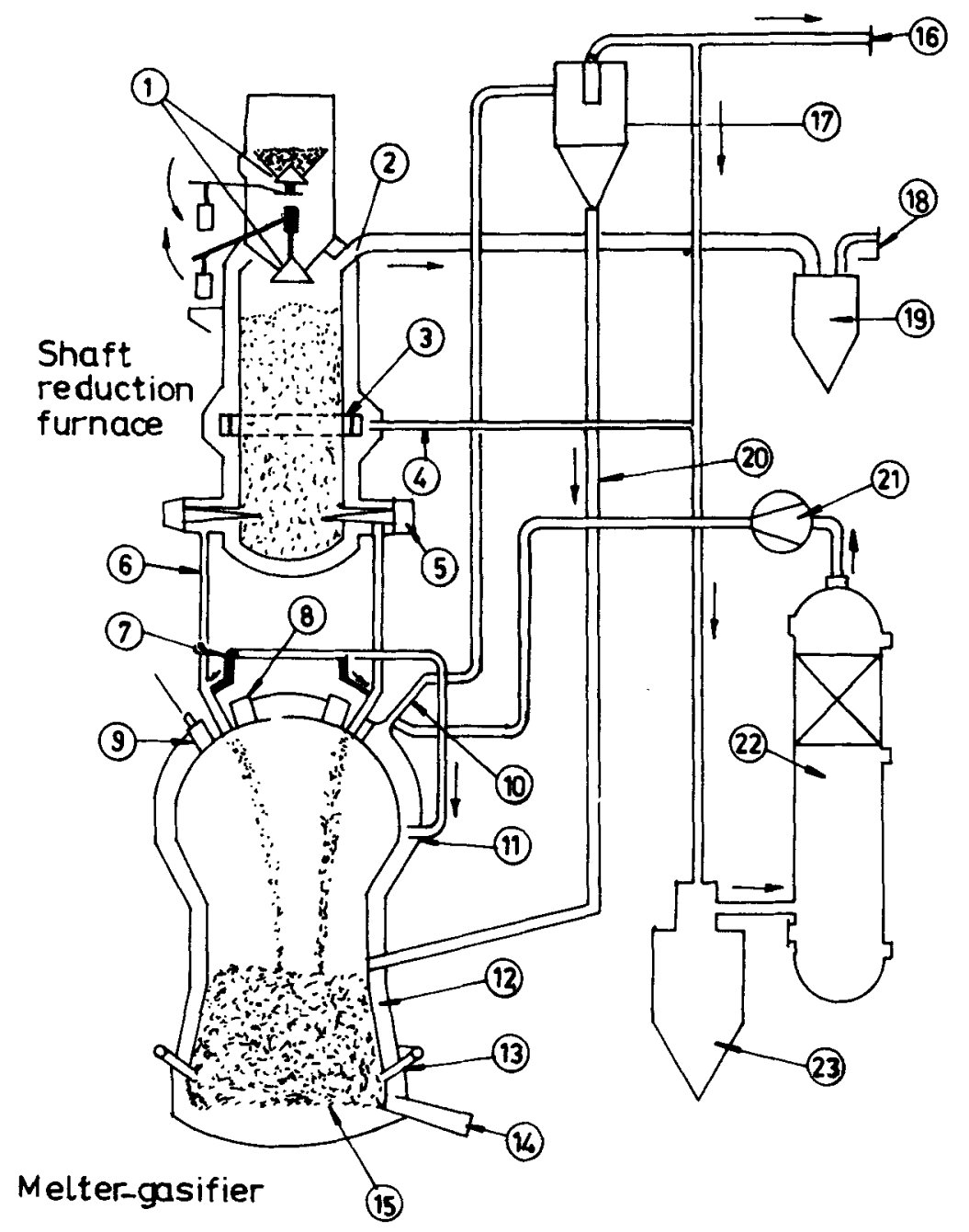

Figure 7. Flowsheet of a KR piant: 1) ore double bell, 2) top gas outlet, 3) bustle for reduction gas, 4) reduction gas pipeline, 5) sponge iron discharge screw, 6) sponge iron chutes, 7) cooling gas bustle to sponge iron chutes, 8) coal feeder 9) gas outlet, 10) cooling gas inlet, 11) cooling gas inlet to hood, 12) coke fluidized bed, 13) oxygen tuyeres, 14) hot metal and slag tapping 15) hot metal bath, 16) hot surplus gas, 17) hot cyclone, 18) scrubbed top gas, 19) top gas scrubber, 20) fipes, 21) cooling gas fan, 22) cooling gas scrubber, 23) venturi scrubber.

between the amount of gas that is produced in the final reduction and the amount that is required for pre-reduction. Thus, the optimum utilization of the reducing agent is obtained with minimum recirculation of gas. The final reduction stage is considered by SKF to be the most important part of the process. This stage consists of a hollow space in a shaft filled with coke. It is analogous to the raceway combustion zone in front of a tuyere in a blast furnace.

Pre-reduced iron ore fines are injected into the smelt-reduction zone together with slag-forming constituents and reducing agents such as powdered coal. Heat energy is 
supplied from the plasma generator (torch). The principal reductant is coal or oil. The purpose of the coke is to form a reaction space in the shaft permeable to gases and capable of withstanding high temperatures. Coke is also needed to ensure reducing conditions at the refractory walls so as to compensate for small fluctuations in the feed of the reductant and to provide a uniform carbon content in the hot metal. The gas that is produced during final reduction consists primarily of carbon monoxide and hydrogen, together with small amounts of carbon dioxide and water vapor. The carbon dioxide and water vapor are reduced by the hot coke higher up in the shaft, so that the exit gas is a mixture of carbon monoxide and hydrogen at a temperature in the range of 1000 to $1200^{\circ} \mathrm{C}$. The mixture of carbon monoxide and hydrogen gas from the shaft furnace is cooled to about $800^{\circ} \mathrm{C}$ and cleaned in a cyclone. It is then used in the prereduction stage. A small part of the gas from the final reduction shaft is cooled and compressed and used partly as process gas for the plasma generator and partly as the carrier for feeding the pre-reduced iron ore and the slag formers into the shaft furnace.

The pre-reduction stage consists of two fluidized beds in series. The temperature for pre-reduction is in the range of 700 to $800^{\circ} \mathrm{C}$, and the degree of reduction is 50 to $60 \%$. The gas from the pre-reduction stage contains 10 to $15 \%$ carbon monoxide plus hydrogen, and is used for drying and preheating incoming iron ore concentrates. In the fluidized beds, the gas velocity is higher than normal. Fines are blown out of the bed. These fines are recovered in the air-cleaning cyclones. They are not returned to the fluidized bed, but go instead directly to the final-reduction shaft furnace. Figure 8 is a schematic flowsheet for the Plasmasmelt process. The energy requirements pertonne of hot metal, using coal as reductant are-coke $50 \mathrm{kgs}$, coal $200 \mathrm{kgs}$ and electricity $1200 \mathrm{kWh}$. Waste dust from steel plants, flux dust rich in zinc etc., can also be plasma reduced in the same set-up to obtain iron. The energy requirements in such a case are slightly different, ie, coke $50 \mathrm{kgs}$, coal $150 \mathrm{kgs}$, electricity $1500 \mathrm{kWh}$.

\section{Discussion}

The three processes that have reached the precommercial stage offer interesting contrast in approach but yet end up with comparable performances. In the Inred, the ore is

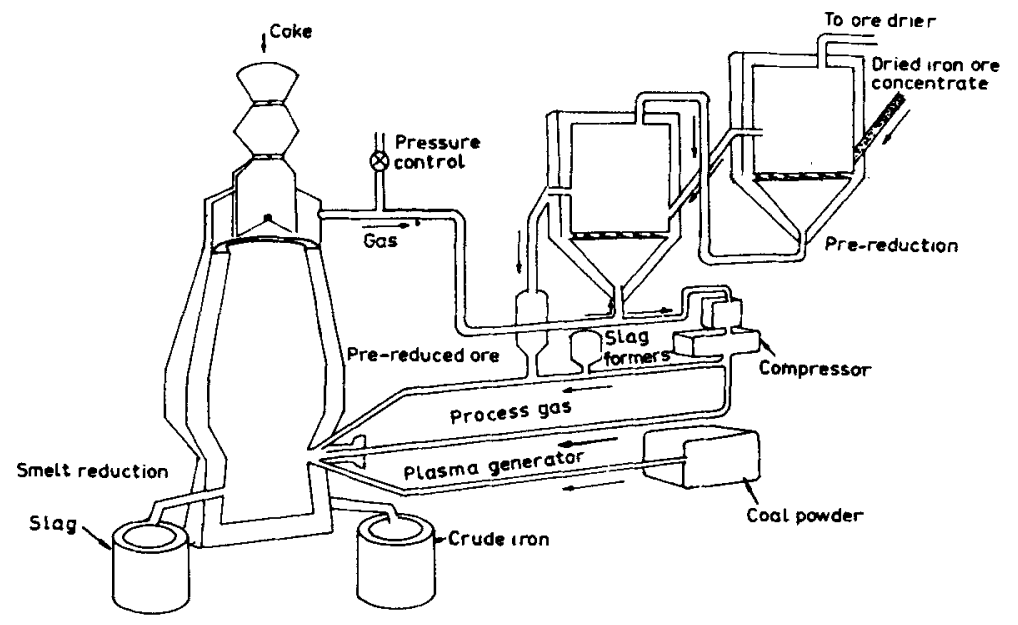

Figure 8. Schematic of a plasmasmelt plant 
preheated to a very high temperature and only partly reduced ( $30 \%$ oxygen removal). This preheated charge is smelted to iron and slag using electrical energy. In the Plasmasmelt, the ore is $50 \%$ reduced and this ore is reduced using the required amount of carbonaceous matter and all the energy is supplied as electrical energy. In the KR process, a highly reducing gas is produced in the melter-gasifier where energy for smelting the $95 \%+$ reduced iron ore is supplied. In table 11 , the fuel requirements for all the processes are compared. It is assumed that coal of $6000 \mathrm{kcal} / \mathrm{kg}$ is used with $15 \%$ ash. It is also assumed that the same coal can be burnt in a power plant to produce power with $30 \%$ efficiency. All of them use about the same quantity of ore while the flux requirement will be minimum for Plasmasmelt and maximum for KR.

It is interesting to note that both the Plasmasmelt and Inred can directly use beneficiated ore. Also, the need for beneficiated coal can be only $275 \mathrm{kgs}$ for Plasmasmelt whereas $800 \mathrm{kgs}$ are required for Inred and about $1600 \mathrm{kgs}$ for KR.

Government is negotiating with Boliden, the developers of Inred and Voest Alpine, the owners of the KR process. It is proposed that an extensive $R$ \& $D$ programme should be supported along with the import of these technologies (DST 1981; Ramachandran 1984a). The successful adaptation of one or all these processes should be of great value to India.

We are now exporting almost 20 million tonnes of iron ore at very low prices and it would be preferable to convert this to iron for our use as iron ore prices have not been remunerative (Rao 1982b; Ramachandran 1984b) (table 12).

Table 11. Raw material requirement for the new ironmaking processes

\begin{tabular}{lccccc}
\hline & & \multicolumn{5}{c}{ Fuel/energy } \\
\cline { 3 - 6 } Process & $\begin{array}{c}\text { Iron ore } \\
\mathbf{k g} / \text { THM }\end{array}$ & $\begin{array}{c}\text { Coal } \\
\mathrm{kg} / \mathrm{THM}\end{array}$ & $\begin{array}{c}\text { Coke } \\
\mathrm{kg} / \mathrm{THM}\end{array}$ & $\begin{array}{c}\text { Power } \\
\mathrm{kWh} / \mathrm{THM}\end{array}$ & $\begin{array}{c}\text { Equivalent coal } \\
\mathbf{k g} / \mathrm{THM}\end{array}$ \\
\hline Inred & 1600 & 800 & - & - & 800 \\
KR & 1600 & 1600 & - & 150 & 1665 \\
Plasmasmelt & 1600 & 200 & 50 & 1200 & 795 \\
\hline
\end{tabular}

Table 12. World iron ore prices in 1980 (constant dollars per tonne)

\begin{tabular}{ll}
\hline Year & Price \\
\hline 1960 & $64 \cdot 8$ \\
1965 & $57 \cdot 1$ \\
1970 & $57 \cdot 2$ \\
1973 & $40 \cdot 1$ \\
1975 & $37 \cdot 8$ \\
1980 & $26 \cdot 7$ \\
\hline
\end{tabular}

Source: World Bank, quoted in the Economic Times $17 / 2 / 1984$. 


\section{Conclusion}

The new ironmaking processes offer the possibility of producing a better grade of iron than our blast furnaces. This should also lead to better steelmaking practices. Fortunately, we are again at a stage when new technologies ideal for our conditions are being developed and we have a chance to take maximum advantage of these, to develop them and to adapt them to our needs. This same challenge was there in the late fifties. At that time however, we had not developed the scientific and technological base we possess now.

The challenge today is to take full advantage of this opportunity and use science and technology to utilize our vast resources for iron and steelmaking by imaginative assimilation, adaptation and modification of these new developments to our needs.

\section{References}

Anon 1982 Met. Bull. Mon., November p 73

Boylan M C 1975 The case of US blast furnaces, (New York: Praeger) p 184

Chatterjee A, Singh R, Pandey B D 1983 Steel India 6: 57-88

DST 1981 Inred technology, Report of the Department of Science \& Technology Expert Committee,

Government of India, November

Dilley D R, Macbride D L 1967 Iron Steel Eng. 44: 131-152

Elvander H I, Edenwall I A, Hellestam S C J 1979 Ironmaking Steelmaking 12: 235-244

Elvander H I 1982 Iron Steel Eng. 59: 57-60

Gaines J M 1974 (ed.) BOF steelmaking AIME p 4

Hadfield R 1912 J. Iron Steel Inst. 12: 134-186

Heath J M 1839 J. R. Asiatic Soc. 5: 390-397

Hebbert R A 1981 Metals and Materials p 27

Hogan W T, Koelble F T 1981 Direct reduction as ironmaking alternative in the United States, EDA Project No 99-26-09886-10, Fordham University, USA

Irving R R 1981 Iron Age July 6, p 21

Kajikawa S, Yamamoto R, Kishimoto S, Fukushima T 1983 Iron Steelmaker 10(9): 34-43

Lownie H W, Mcleer T J, Davidson R S, Moody C W 1982 Technical and economic feasibility for the production of direct reduced iron in Minnesota, Battelle Report, Columbus, USA

Mastey A D 1982 Metal Producing p 57

Ramachandran S 1984a, Programme on know-why for new ironmaking process, Foundation to Aid Industrial Recovery, Bangalore

Ramachandran S 1984b Environmental impact of mining and process of minerals, Paper presented at the Tutorial symposium, Indian Institute of Science, Bangalore, June

Rao K N P 1974 Hist. Metall. Bull. 4: 16-19

Rao K N P 1982a The metallurgist and materials technologist, October 1982, p 468

Rao T R 1982b State enterprise Vol. I p 174

Rickard T A 1929 J. Iron Steel Inst. 29: 323-342

Sidhu S S 1983 The steel industry in India: problems and prospectives (New Delhi: Vikas)

Stephenson R L 1980 (ed.) Direct reduced iron: technology and economics of production and use AIME p 73 Stephenson R L 1983 Iron Steelmaker 10(1): 19-22 